\title{
BIBLIOMETRIC ANALYSIS OF PSYCHOTHERAPY RESEARCH: PERFORMANCE ASSESSMENT AND POSITION IN THE JOURNAL LANDSCAPE
}

\author{
Anthony F. J. van Raan \\ Martijn S. Visser \\ Thed N. Van Leeuwen \\ Erik van Wijk \\ Leiden University
}

The authors provide an overview of advanced bibliometric methods for (a) an objective and transparent assessment of journal performance and (b) positioning of a journal in relation to other journals. These methods are applied to Psychotherapy Research, an international journal within the field of clinical psychology. In the first analysis, the authors focus on journal performance in an international comparative perspective (i.e., the performance of the journal in relation to all other journals in the same field of science) and introduce a novel type of journal impact factor. In the second analysis, the authors position the journal on the basis of total citation relations among all relevant journals, including those outside the specific field of science to which the journal belongs. A multitude of interdisciplinary relations between the journal under investigation and many other journals is revealed. The investigators discuss briefly the potential of such a "journal citation mapping" for unraveling interdisciplinary developments and "interfaces" between different fields of science.

\section{Why Bibliometric Analysis?}

Communication (i.e., exchange of research results) is a crucial aspect of science. Bibliometric assessment of research performance is based on one central assumption: Scientists who have something important to say publish their findings vigorously in the open, international journal (serial) literature, thus providing a proof of their performance.

Peer review is typically a qualitative assessment of research performance. It is and must remain the central process of quality judgment in science. However, it is not without disadvantages (Horrobin, 1990; Moxham \& Anderson, 1992). Bibliometric indicators discussed here represent the quantitative side. Quantitative elements are

\footnotetext{
We thank Peter Negenborn for his work on the automation of journal-specific bibliometric analysis as well as the anonymous referees for valuable comments and suggestions for improvements of the data analytical procedures.

Correspondence concerning this article should be addressed to Anthony F. J Van Raan, Centre for Science and Technology Studies, Leiden University, Wassenaarseweg 52, P.O. Box 9555, 2300 RB Leiden, The Netherlands. E-mail: vanraan@cwts.leidenuniv.nl.
} 
clearly also present in peer review (e.g., number of publications in high-prestige scientific journals). Conversely, citations given to research work can be seen as judgments, or votes of colleague-scientists in favor of the work cited.

Publications are not the only, but certainly very important, elements in this knowledge exchange process. Work of high quality provokes reactions of colleague-scientists. They are the international forum, the "invisible college" by which research results are discussed. In most cases, these colleague-scientists play their role as a member of the invisible college by referring in their own work to earlier work of other scientists.

The process of citation is complex, and it is certainly not an ideal monitor of scientific performance. This is particularly true on a statistically low aggregation level (e.g., an individual researcher). However, the application of citation analysis to the work of a research group as a whole over a longer period of time does yield, in many situations, a strong indicator of scientific performance as a proxy measure of scientific quality (Rinia, Van Leeuwen, Van Vuren, \& Van Raan, 1998; Van Raan, 1996). The same is true for another type of publication aggregate: a scientific journal. An important, absolutely necessary condition is that applied citation analysis is part of an advanced, technically highly developed bibliometric method.

We present the results of a bibliometric analysis applied to Psychotherapy Research. We first discuss the specific journal performance indicators and then apply the indicators directly to Psychotherapy Research from 1995 to 2002. With help of these indicators, we are able to establish the role of the journal in an international context. Second, we address a similar analysis, enabling us to find characteristics of the users of the work published in Psychotherapy Research. Third, we discuss a number of additional indicators that are necessary to create a "science map" (i.e., an abstract landscape in which the position of Psychotherapy Research in relation to a larger number of related journals is depicted).

\section{Bibliometric Indicators Applied to Psychotberapy Research}

Research output is defined as the number of articles of the journal to the extent they are covered by the Science Citation Index (SCI), Social Science Citation Index (SSCI), as in the case of Psychotherapy Research, or the Arts \& Humanities Citation Index, together constituting the Institute for Scientific Information (ISI) database. ${ }^{1}$ For purposes of this study, normal articles (including proceedings papers published in journals), letters, notes, and reviews (excluding abstracts, obituaries, corrections, editorials, and so on) are considered as articles.

We developed data algorithms and the necessary software routines to calculate a set of standardized bibliometric indicators. We discuss these indicators-also used for research evaluation-on the basis of the results of our analysis of Psychotherapy Research (from 1995-2002, volumes 5-12). For the use of bibliometric indicators in the social and behavioral sciences, we refer to the following: for social psychology, Meertens, Nederhof, and Wilke (1992) and Nederhof, Van Leeuwen, and Visser (1997); for psychology as a whole, VSNU (1999) and Nederhof, Van Leeuwen, and Visser (2000); for a general overview, Van Raan (1998). To provide the reader with an overview, we present these general bibliometric research performance indicators in Appendix A.

\footnotetext{
${ }^{1}$ The SCI, SSCI, Arts \& Humanities Citation Index, and related citation indexes are produced and published by the Institute for Scientific Information (ISI) in Philadelphia.
} 
Table 1 provides a bibliometric analysis of the journal with seven indicators: number of papers published, number of citations with and without author selfcitations, mean number of citations per publication (CPP), percentage of not-cited papers, CPP normalized by the mean field citation score $\left(\mathrm{FCS}_{m}\right)$ ratio, and percentages of author self-citations (Scit). An example of the analytic scheme is as follows: For papers published in 1995, citations are counted during the period 1995 to 2002; for papers published in 1996, citations are counted in 1996 to 2002. Generally, the average peak in the number of citations is in the fourth year after publication (Moed, De Bruin, \& Van Leeuwen, 1995). There is always debate regarding papers that are "never" cited. Therefore, we stress that this percentage of noncited papers concerns, like all other indicators, the given time period. It is very possible that publications not cited within such a period will be cited after a longer time. This is clearly obvious when comparing this indicator for the older and the more recent volumes. Therefore, one has to be cautious with notions such as not-cited or never-cited papers.

Because we deal here with a journal and not a research group or institute, the indicator CPP equals our standard journal impact indicator journal citation score (JCS), and it constitutes a novel journal impact factor (see Van Raan, 1996).

How do we know that a certain volume of citations or a certain citation-perpublication value is low or high? To answer this question, it is crucial to make a comparison with (and normalization to) a well-chosen international reference value and to establish a reliable measure of relative, internationally field-normalized impact. Furthermore, because overall worldwide citation rates are increasing, it is also necessary to normalize the measured impact of a journal to reference values.

Thus, the next step is to relate the indicators calculated so far with the "environment" of the journal, particularly with the impact of other journals in the same field (clinical psychology). To this end, we developed an international journal reference level, a field-based average field citation score (FCS). This indicator is based on

TABLE 1. Bibliometric analysis of Psychotherapy Research, 1995-2002

\begin{tabular}{lrrrrrrr}
\hline Volume & & & & & \multicolumn{2}{c}{$\mathrm{CPP} /$} \\
& $\mathrm{P}^{\mathrm{a}}$ & $\mathrm{C}$ & $\mathrm{C}+\mathrm{sc}$ & $\mathrm{CPP}$ & Pnc & FCS $_{m}{ }^{\mathrm{b}}$ & Scit \\
\hline All & 205 & 683 & 921 & 3.33 & $35 \%$ & $\mathbf{0 . 8 2}-$ & $26 \%$ \\
5 & 22 & 125 & 154 & 5.68 & $9 \%$ & $\mathbf{0 . 6 6}-$ & $19 \%$ \\
6 & 22 & 128 & 181 & 5.82 & $18 \%$ & $\mathbf{0 . 7 9}$ & $29 \%$ \\
7 & 27 & 124 & 171 & 4.59 & $7 \%$ & $\mathbf{0 . 7 7}-$ & $27 \%$ \\
8 & 29 & 171 & 216 & 5.90 & $21 \%$ & $\mathbf{1 . 1 6}$ & $21 \%$ \\
9 & 28 & 64 & 94 & 2.29 & $18 \%$ & $\mathbf{0 . 6 6}-$ & $32 \%$ \\
10 & 33 & 59 & 76 & 1.79 & $36 \%$ & $\mathbf{1 . 0 3}$ & $22 \%$ \\
11 & 25 & 12 & 27 & 0.48 & $84 \%$ & $\mathbf{0 . 7 6}$ & $56 \%$ \\
12 & 19 & 0 & 2 & 0.00 & $100 \%$ & $\mathbf{0 . 0 0}-$ & $100 \%$ \\
\hline
\end{tabular}

Note. $\mathrm{P}=$ number of papers published; $\mathrm{C}=$ total number of citations; $\mathrm{C}+\mathrm{sc}=$ number of citations with author self-citations; $\mathrm{CPP}=$ mean number of citations per publication; Pnc=percentage of not-cited papers; $\mathrm{FCS}_{m}=$ mean field citation score; SCcit = percentage of author self-citations.

${ }^{a}$ The number of publications (P) for volume 12 is less than the "real" number of publications, because we work with database year and some of the volume 12 publications will be covered by the database in 2003. ${ }^{b}$ The minus sign refers to our statistical analysis. The statistical test developed by Glänzel (1992; Schubert \& Glänzel, 1983) decides whether the average impact of a research group or institute (CPP) or of a journal (in that case $\mathrm{CPP}=\mathrm{JCS}_{m}$ ) differs significantly from the world citation average $\left(\mathrm{FCS}_{m}\right)$ of the field(s) in which the group, institute, or journal is active. Significant deviations $(p=.05)$ above or below the field average field are indicated by "+" or "-" after the values of the indicators CPP/FCS ${ }_{m}$. 
the citation rate of all papers (worldwide) published in all journals of the field. ${ }^{2}$ In research work, often more than one field is involved; even one specific journal can be categorized to more than one field. So we generally use the $\mathrm{FCS}_{m}$ of the fields concerned. We use the same calculation procedure as the one we applied in the calculation of CPP. We give an example of the computational procedure in Appendix B.

If the $\mathrm{CPP} / \mathrm{FCS}_{m}$ ratio is above 1.0, the impact of the journal, or a given volume, exceeds the field-based (i.e., all journals in the field clinical psychology) world average. For Psychotherapy Research as a whole, this ratio is 0.82 , which means that the journal performs to about slightly below the field average. We observe that the impact of volume 5 is quite below the field average and that of volume 8 is above this average.

We regard the internationally standardized impact indicator $\mathrm{CPP} / \mathrm{FCS}_{m}$ as our "crown" indicator. As discussed, this indicator enables us to observe immediately whether the performance of a journal is far below (indicator value $<0.5$ ), below (indicator value $0.5-0.8)$, about (0.8-1.2), above (1.2-1.5), or far above (>1.5) the average impact of the field.

We claim that our indicators CPP (for a journal, JCS) and also CPP/FCS ${ }_{m}$ (for a journal, JCS/FCS ${ }_{m}$ ) are novel journal indicators that characterize a journal better than the commonly used ISI journal IF. The unique aspect of our journal impact indicators is that we take into account the type of paper (e.g., letters, normal article, review) as well as the specific years in which the papers were published. This is absolutely necessary because the average impact of journals may have considerable annual fluctuations and large differences per article type (see Moed \& Van Leeuwen, 1995, 1996). As discussed, a simple example to illustrate the computational procedure is given in Appendix B.

For Scit, about $30 \%$ is normal, so the rates for this journal are certainly not high. Self-citations are often earlier than citations given by other researchers. This phenomenon is evident for the most recent volumes (see Table 1).

\section{Characteristics Of Citing Publications}

The influence of research in a specific field on other fields is an important aspect of science: It is the main driving force of knowledge diffusion and is the basis of interdisciplinarity. Bibliometric analysis provides a unique method to measure interfield influence by means of a profile of the citing publications. In other words, we break down the citing publications into fields. Analysis of this citing profile of a journal reveals the influence of the journal on other fields. Thus, citing papers represent the knowledge users.

We present the results of this analysis in Figure 1 (underlying data are presented in the Appendix C). Obviously, the majority of the citing publications (54\%) are in the same field to which the cited publications of Psychotherapy Research belong (clinical psychology). However, a considerable number of citing papers are in the fields of psychiatry ( $8 \%$ in SSCI journals and 5\% in SCI journals), multidisciplinary (i.e., general) psychology (6\%), and applied psychology (5\%).

\footnotetext{
${ }^{2}$ We use the definition of fields based on a classification of scientific journals into categories developed by ISI. Although this classification is not perfect, it is currently the most suitable classification available in terms of an automated procedure within our data system. In the case of the journal analyzed in this study, Psychotherapy Research, the field (ISI category) is clinical psychology.
} 


\title{
FIGURE 1: IMPACT PROFILE OF THE CITING PAPERS OF PSYCHOTHERAPY RESEARCH, 1995-2002
}

\author{
'Knowledge Us ers' \\ SHARE AND LEVEL OF IMPACT PER FIELD OF THE CITING PAPERS
}

FIELD

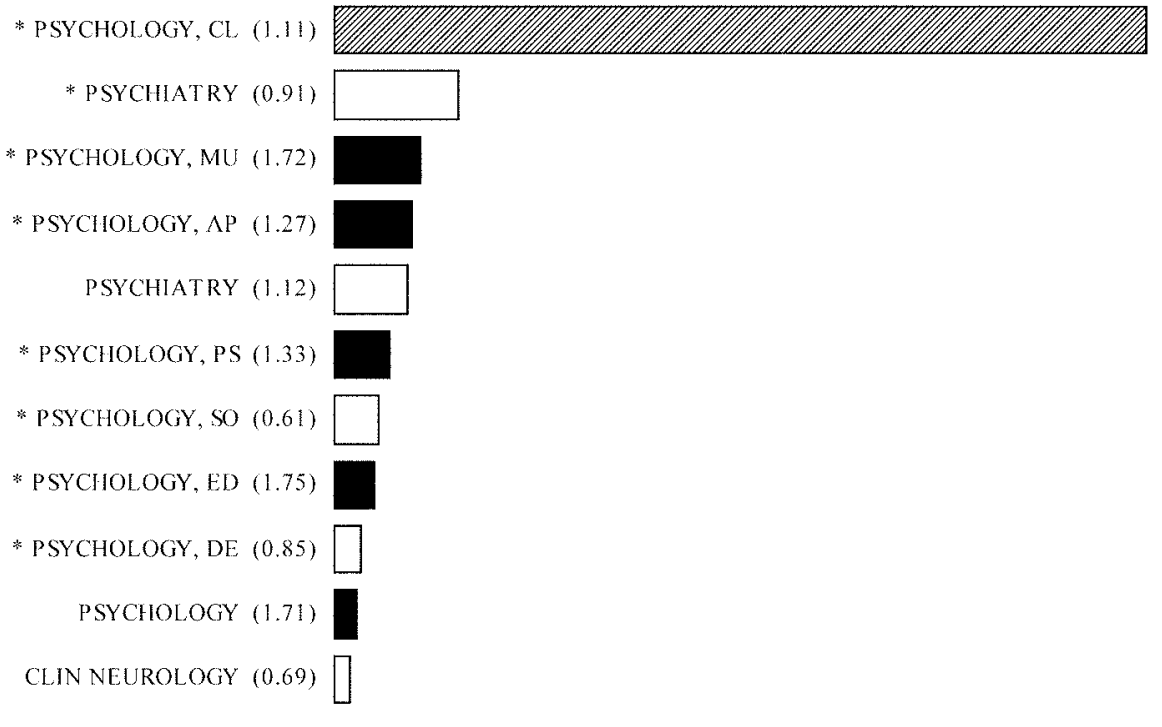

$\begin{array}{llllll}0 \% & 10 \% & 20 \% & 30 \% & 40 \% & 50 \%\end{array}$ Share of Psychotherapy Research im pact

IMPACT: $\quad$ LOW $\square$ AVERAGE WIIITIDIIIX

FIGURE 1. CPP/FCS values for the citing papers in a specific field are given behind the name of the field. Low impact: $\mathrm{CPP} / \mathrm{FCS}<0.8$; average impact: $0.8<\mathrm{CPP} / \mathrm{FCS}<1.2$; high impact: $\mathrm{CPP} / \mathrm{FCS}>1.2$. Fields indicated with an asterisk concern journal categories covered by the SSCI, and fields without an asterisk concern journal categories covered by the SCI. *Psychology, $\mathrm{CL}=$ clinical psychology; *Psychology, MU=multidisciplinary (i.e., general) psychology; *Psychology, AP=applied psychology; *Psychology, PS = psychoanalytical research; *Psychology, SO=social psychology; "Psychology, $\mathrm{ED}=$ educational psychology; *Psychology, DE=developmental psychology.

All our standard indicators are applied to the citing papers of Psychotherapy Research. The majority of the citing papers, received from same-field clinical psychology $(54 \%)$, are rather high-impact papers $(\mathrm{CPP} / \mathrm{FCS}=1.11)$, indicating that the papers in Psychotherapy Research are cited by relatively high-impact papers. In particular, citing papers from multidisciplinary/general psychology (journals in the SSCI) are highly cited papers themselves $(\mathrm{CPP} / \mathrm{FCS}=1.72)$, and also citing papers from applied psychology $(\mathrm{CPP} / \mathrm{FCS}=1.27)$, from psychoanalytical research $(\mathrm{CPP} /$ $\mathrm{FCS}=1.33)$, and from educational psychology $(\mathrm{CPP} / \mathrm{FCS}=1.75)$ are highly cited.

In the tail of the distribution of citing papers among fields (Appendix $\mathrm{C}$ ), we find fields such as clinical neurology, family studies, and substance abuse. It is evident that these fields clearly appear in the journal landscape of Psychotherapy Research. 
As can be seen in Appendix C, we also have calculated the indicator $\mathrm{CPP} / \mathrm{JCS}_{m}$, which gives the impact of the citing papers normalized to the average citation impact of the journals in which the citing papers are published. The $\mathrm{JCS}_{m} / \mathrm{FCS}_{m}$ ratio indicates the impact level of the journals in which the citing papers were published. If the value is above 1.0, the average impact of the journals of the citing papers exceeds the average impact of the fields to which the journals of the citing papers belong. Thus, it provides an indication of the impact level, or status, of the journals in which Psychotherapy Research papers are cited. For most fields, the indicator value is about or above to far above 1.0. We conclude that Psychotherapy Research papers are mostly cited in good journals.

\section{Journal Landscape: Bibliometric Mapping of Journals and Their Relations}

\section{Citation Characteristics as a Basis for Mapping}

The first step of the bibliometric mapping procedure is to find four journals with which Psychotherapy Research has the strongest citation relations (in the cited as well as citing mode; Table 2). Psychotherapy Research and four additional journals are labeled seed journals. (Although there is no special reason to use four additional journals, it has been our experience that this number is sufficient to successfully start the mapping procedure.)

Each of these five seed journals are used as a starting point for further selection of related journals on the basis of the percentage of citations given to or received by at least one of the seed journals. This percentage must exceed a specific threshold value that depends on the total volume of citations received by those seed journals. ${ }^{3}$ With this iterative procedure, an additional 74 journals were identified. Table 2 provides an overview of the citation thresholds that were adopted.

Table 3 provides additional quantitative information on the citation flows to and from the five seed journals, focusing on the journals with the strongest citation

\section{TABLE 2. Input and Selection Parameters of the First-Step Journal Selection Procedure}

\begin{tabular}{lcc}
\hline & \multicolumn{2}{c}{ Citation threshold } \\
\cline { 2 - 3 } Seed journal & Citing\% & Cited $\%$ \\
\hline Archives of General Psychiatry & 1 & 1 \\
Journal of Consulting and Clinical Psychology & 1 & 1 \\
Journal of Counseling Psychology & 1 & 1 \\
Psychotherapy & 1 & 1 \\
Psychotherapy Research & 3 & 2 \\
\hline
\end{tabular}

Note. Citing $\%=$ percentage of citations given to at least one of the seed journals; cited $\%=$ percentage of citations received by at least one of the seed journals.

\footnotetext{
${ }^{3}$ The threshold value was defined as a percentage dependent on the total volume of citations received or given by a seed journal. It is $10 \%$ by $3-50$ citations, $7.5 \%$ by $51-75$ citations, $5 \%$ by $76-100$ citations, $4 \%$ by $101-150$ citations, $3 \%$ by $151-250$ citations, $2 \%$ by $251-500$ citations, and $1 \%$ by 501 and more citations. Current research is going on to improve the mathematical properties of this threshold function.
} 
interrelationships (those accounting for $>5 \%$ of their total number of citations, including journal self-citations).

\section{Additional Publication and Citation Characteristics of Journals}

Table 4 presents quantitative data on several bibliometric characteristics for all 79 selected journals (full names of the journals with abbreviations are given in Appendix D). These characteristics are formulated in terms of indicators and concern the role of a journal in its share of publications and its role in the citation traffic within the entire set of journals. With these indicators, we are able to assess a journal's relative importance in a broader perspective, particularly its share in publications and citations within a set of related journals.

The citation coverage of a journal is defined as the ratio of the percentage of citations received from or given to the set of selected journals, including the journal self-citations and the same to all SCI/SSCI-covered journals (i.e., the entire ISI database). This indicator identifies whether a journal is more general (lower citation coverage values) or more focused to the set of related journals (i.e., more field specific [higher citation coverage values]). Thus, this indicator measures the extent to which the citation traffic of a journal is concentrated within the set of selected journals. Table 4 indicates that this is clearly more the case for Psychotherapy Research than for Lancet (69\% vs. 6.9\%). These journal citation data include all document types.

The publication share concerns the number $(p)$ and percentage $(p \%)$ of the contribution of each journal to the total number of journal publications in the entire

TABLE 3. Citation Interrelationships of Seed Journals

\begin{tabular}{|c|c|c|c|c|}
\hline Citing journal & Cited journal & Citations & Total citing & $\%$ js \\
\hline \multirow{2}{*}{ Arch Gen Psychia } & Am J Psychia & 361 & 4,260 & 8.47 \\
\hline & Arch Gen Psychia & 622 & 4,260 & 14.60 \\
\hline$J$ Cons Clin Psych & $J$ Cons Clin Psych & 453 & 2,744 & 16.51 \\
\hline \multirow[t]{4}{*}{ J Coun Psych } & Coun Psyc & 79 & 1,311 & 6.03 \\
\hline & J Cons Clin Psych & 78 & 1,311 & 5.95 \\
\hline & J Coun Psych & 224 & 1,311 & 17.09 \\
\hline & J Pers Social Psych & 83 & 1,311 & 6.33 \\
\hline \multirow[t]{4}{*}{ Psyc Res } & J Cons Clin Psych & 102 & 497 & 20.52 \\
\hline & J Coun Psych & 38 & 497 & 7.65 \\
\hline & Psyc Res & 52 & 497 & 10.46 \\
\hline & Psychotherapy & 29 & 497 & 5.84 \\
\hline \multirow[t]{4}{*}{ Psychotherapy } & J Cons Clin Psych & 151 & 1,197 & 12.61 \\
\hline & $J$ Coun Psych & 73 & 1,197 & 6.10 \\
\hline & Prof Psych Res Pra & 69 & 1,197 & 5.76 \\
\hline & Psychotherapy & 118 & 1,197 & 9.86 \\
\hline Cited journal & Citing journal & Citations & Total cited & $\%$ js \\
\hline Arch Gen Psychia & Arch Gen Psychia & 622 & 21,503 & 2.89 \\
\hline J Cons Clin Psych & J Cons Clin Psych & 453 & 10,170 & 4.45 \\
\hline J Coun Psych & J Coun Psych & 224 & 1,673 & 13.39 \\
\hline \multirow[t]{2}{*}{ Psyc Res } & Psyc Res & 52 & 238 & 21.85 \\
\hline & Psychotherapy & 18 & 238 & 7.56 \\
\hline Psychotherapy & Psychotherapy & 118 & 692 & 17.05 \\
\hline
\end{tabular}

Note. See Appendix D for complete journal titles. \%js= percentage of journal self-citations. 
TABLE 4. Bibliometric Indicators of All Selected Journals

\begin{tabular}{|c|c|c|c|c|c|c|c|c|}
\hline \multirow[b]{2}{*}{ Journal } & \multirow{2}{*}{$\begin{array}{c}\text { Citation } \\
\text { coverage }^{\mathrm{a}}\end{array}$} & \multicolumn{2}{|c|}{$\begin{array}{c}\text { Publication } \\
\text { share }^{\mathrm{b}}\end{array}$} & \multicolumn{2}{|c|}{ Citation share } & \multirow[b]{2}{*}{$\mathrm{JSc} \%$} & \multirow[b]{2}{*}{ IF } & \multirow[b]{2}{*}{$\mathrm{JCS} / \mathrm{FCS}$} \\
\hline & & $\mathrm{p}$ & $\mathrm{p} \%$ & $\mathrm{c}^{\mathrm{c}} \mathrm{c}^{\mathrm{C}}$ & c-all\% ${ }^{\mathrm{d}}$ & & & \\
\hline Act Psyc Sc & 38.3 & 144 & 1.3 & 2.0 & 0.8 & 8.1 & 1.97 & 0.85 \\
\hline Addi Beha & 37.5 & 76 & 0.7 & 0.6 & 0.3 & 7.7 & 0.95 & 0.85 \\
\hline Am J Med Genet & 17.3 & 537 & 4.9 & 2.4 & 2.2 & 15.5 & 2.22 & 0.52 \\
\hline Am J Orth & 35.7 & 37 & 0.3 & 0.5 & 0.2 & 3.1 & 0.87 & 0.44 \\
\hline Am J Psyc & 28.4 & 9 & 0.1 & 0.0 & 0.0 & 2.6 & 0.20 & 0.36 \\
\hline Am J Psychia & 35.9 & 302 & 2.8 & 6.0 & 2.7 & 6.8 & 6.18 & 2.73 \\
\hline Am J Publ Heal & 14.4 & 312 & 2.9 & 1.3 & 1.5 & 8.2 & 2.60 & 2.21 \\
\hline$A m P s y c$ & 26.1 & 57 & 0.5 & 1.3 & 0.8 & 6.2 & 5.89 & 5.24 \\
\hline Appl Prev Psych & 52.5 & 7 & 0.1 & 0.1 & 0.0 & 1.8 & 1.56 & 0.61 \\
\hline Arch Gen Psychia & 38.6 & 108 & 1.0 & 5.2 & 2.2 & 4.8 & 10.71 & 5.00 \\
\hline Aus Psyc & 49.7 & 35 & 0.3 & 0.3 & 0.1 & 9.4 & 0.29 & 0.82 \\
\hline Beba Res Ther & 44.1 & 103 & 0.9 & 1.4 & 0.5 & 14.1 & 1.91 & 1.31 \\
\hline Behav Ther & 54.6 & 54 & 0.5 & 0.9 & 0.3 & 6.3 & 1.28 & 1.39 \\
\hline Biol Psychia & 32.7 & 235 & 2.2 & 3.8 & 1.9 & 7.0 & 5.09 & 1.56 \\
\hline Brit J Guid Coun & 52.2 & 26 & 0.2 & 0.1 & 0.0 & 13.5 & 0.45 & 1.71 \\
\hline Brit J Med Psych & 32.5 & 39 & 0.4 & 0.2 & 0.1 & 7.5 & 0.95 & 0.48 \\
\hline Brit J Psychia & 37.2 & 193 & 1.8 & 3.4 & 1.5 & 8.7 & 3.57 & 1.88 \\
\hline Can J Psychia Revu C & 46.0 & 96 & 0.9 & 1.2 & 0.4 & 6.5 & 1.46 & 0.67 \\
\hline Care Dev $Q$ & 63.4 & 21 & 0.2 & 0.2 & 0.0 & 18.6 & 0.63 & 1.26 \\
\hline Child Abus Negl & 37.9 & 103 & 0.9 & 0.9 & 0.4 & 18.7 & 1.06 & 1.41 \\
\hline Child Dev & 18.9 & 164 & 1.5 & 1.4 & 1.2 & 15.7 & 2.77 & 2.44 \\
\hline Clin Psych Psyc & 62.4 & 40 & 0.4 & 0.4 & 0.1 & 2.8 & 0.56 & 0.48 \\
\hline Clin Psych Rev & 49.5 & 55 & 0.5 & 1.4 & 0.4 & 1.7 & 2.19 & 1.09 \\
\hline Clin Psych Sci Pra & 64.1 & 53 & 0.5 & 0.5 & 0.1 & 3.3 & 1.20 & 0.84 \\
\hline Cogn Behav Pra & 64 & 84 & 0.8 & 0.3 & 0.1 & 11.0 & 0.57 & 1.05 \\
\hline Cogn Ther Res & 52.8 & 40 & 0.4 & 0.7 & 0.2 & 9.2 & 1.32 & 0.70 \\
\hline Contemp Psychoana & 52.1 & 24 & 0.2 & 0.1 & 0.0 & 40.2 & 0.82 & 0.39 \\
\hline Coun Psyc & 60.3 & 6 & 0.1 & 0.2 & 0.1 & 5.7 & 0.51 & 1.56 \\
\hline Heal Psych & 20 & 48 & 0.4 & 0.5 & 0.4 & 4.7 & 2.77 & 2.21 \\
\hline Int J Grou Psyc & 45.1 & 29 & 0.3 & 0.1 & 0.0 & 29.4 & 0.77 & 0.53 \\
\hline J Abno Child Psych & 43.3 & 47 & 0.4 & 0.8 & 0.3 & 7.2 & 2.34 & 1.49 \\
\hline J Abno Psych & 44.5 & 94 & 0.9 & 2.0 & 0.7 & 9.7 & 3.09 & 2.70 \\
\hline J Affe Disord & 48.3 & 188 & 1.7 & 2.3 & 0.8 & 9.2 & 2.14 & 1.04 \\
\hline$J$ Am Ac Child Adol P & 36.8 & 180 & 1.7 & 2.6 & 1.2 & 15.8 & 3.19 & 1.68 \\
\hline J Behav Ther Exp Psy & 45.2 & 15 & 0.1 & 0.2 & 0.1 & 1.1 & 0.65 & 0.36 \\
\hline J Care Asses & 70.6 & 25 & 0.2 & 0.2 & 0.1 & 22.1 & 0.81 & 1.39 \\
\hline J Care Dev & 51.4 & 21 & 0.2 & 0.1 & 0.0 & 11.3 & 0.31 & 0.49 \\
\hline J Clin Child Psych & 47.8 & 53 & 0.5 & 0.7 & 0.2 & 5.8 & 1.50 & 1.58 \\
\hline$J$ Clin Psych & 36.7 & 131 & 1.2 & 0.7 & 0.3 & 5.7 & 0.85 & 0.56 \\
\hline J Clin Psychia & 38.3 & 295 & 2.7 & 3.6 & 1.5 & 13.7 & 4.44 & 2.58 \\
\hline J Coll Stud Dev & 39.6 & 44 & 0.4 & 0.2 & 0.1 & 23.1 & 0.50 & 0.73 \\
\hline J Cons Clin Psych & 42.2 & 106 & 1.0 & 2.8 & 1.1 & 7.0 & 3.60 & 3.23 \\
\hline J Coun Dev & 51.4 & 52 & 0.5 & 0.4 & 0.1 & 14.3 & 0.38 & 0.74 \\
\hline J Coun Psych & 56.6 & 45 & 0.4 & 0.9 & 0.3 & 15.0 & 1.14 & 1.45 \\
\hline J Huma Psych & 46.4 & 19 & 0.2 & 0.1 & 0.0 & 28.3 & 0.32 & 0.43 \\
\hline JInte Viol & 39.4 & 131 & 1.2 & 0.6 & 0.3 & 11.6 & 1.24 & 1.49 \\
\hline J Mari Fam Ther & 32.2 & 47 & 0.4 & 0.2 & 0.1 & 23.3 & 0.86 & 0.90 \\
\hline
\end{tabular}


TABLE 4. (continued)

\begin{tabular}{|c|c|c|c|c|c|c|c|c|}
\hline \multirow[b]{2}{*}{ Journal } & \multirow{2}{*}{$\begin{array}{c}\text { Citation } \\
\text { coverage }^{\mathrm{a}}\end{array}$} & \multicolumn{2}{|c|}{$\begin{array}{l}\text { Publication } \\
\text { share }^{\mathrm{b}}\end{array}$} & \multicolumn{2}{|c|}{ Citation share } & \multirow[b]{2}{*}{$\mathrm{JSC} \%$} & \multirow[b]{2}{*}{ IF } & \multirow[b]{2}{*}{$\mathrm{JCS} / \mathrm{FCS}$} \\
\hline & & $\mathrm{p}$ & $\mathrm{p} \%$ & $\mathrm{c} \%{ }^{\mathrm{C}}$ & $\mathrm{c}-\mathrm{all} \% \mathrm{~d}$ & & & \\
\hline J Mult Coun Dev & 76.2 & 18 & 0.2 & 0.1 & 0.0 & 14.3 & 0.34 & 0.38 \\
\hline J Nerv Ment Dis & 42.2 & 126 & 1.2 & 1.4 & 0.5 & 6.3 & 1.40 & 0.69 \\
\hline J Neurosci & 8.3 & 1,129 & 10.4 & 5.3 & 10.3 & 10.2 & 8.04 & 2.83 \\
\hline J Pers Social Psych & 19.4 & 171 & 1.6 & 2.5 & 2.1 & 15.6 & 3.67 & 2.70 \\
\hline$J P s y c h$ & 25.5 & 37 & 0.3 & 0.1 & 0.1 & 2.7 & 0.45 & 0.38 \\
\hline J Psych Theo & 42.1 & 30 & 0.3 & 0.1 & 0.0 & 27.0 & 0.39 & 0.63 \\
\hline J Social Behav Pers & 24.7 & 40 & 0.4 & 0.2 & 0.1 & 10.0 & 0.22 & 0.23 \\
\hline J Stud Alco & 32.8 & 95 & 0.9 & 0.9 & 0.5 & 13.1 & 1.89 & 1.31 \\
\hline J Subs Abus Trea & 40.4 & 73 & 0.7 & 0.5 & 0.2 & 11.1 & 0.91 & 0.82 \\
\hline J Voca Behav & 34.9 & 48 & 0.4 & 0.4 & 0.2 & 19.4 & 1.48 & 1.62 \\
\hline$J A M A$ & 10.8 & 377 & 3.5 & 3.9 & 5.9 & 5.2 & 13.03 & 3.66 \\
\hline Lancet & 6.9 & 746 & 6.9 & 3.8 & 9.0 & 4.8 & 7.79 & 2.48 \\
\hline Meas Eval Coun Dev & 45.3 & 17 & 0.2 & 0.1 & 0.0 & 6.1 & 0.54 & 0.62 \\
\hline Med Anthr $Q$ & 16.8 & 24 & 0.2 & 0.1 & 0.1 & 10.3 & 0.59 & 0.89 \\
\hline Neurology & 10.2 & 944 & 8.7 & 3.1 & 4.9 & 9.8 & 4.46 & 2.06 \\
\hline Neuropsychopharmacol & 23.2 & 149 & 1.4 & 1.2 & 0.9 & 4.8 & 4.15 & 1.78 \\
\hline New Engl J Med & 5.8 & 379 & 3.5 & 3.8 & 10.7 & 3.1 & 21.53 & 6.33 \\
\hline Prof Psych Res Pra & 50.9 & 108 & 1.0 & 0.9 & 0.3 & 21.7 & 1.04 & 1.44 \\
\hline Psicothema & 48.7 & 90 & 0.8 & 0.5 & 0.2 & 11.0 & 0.17 & 0.37 \\
\hline Psyc Res & 69.0 & 27 & 0.2 & 0.3 & 0.1 & 14.1 & 1.20 & 1.05 \\
\hline Psych Asses & 44.7 & 45 & 0.4 & 0.5 & 0.2 & 8.9 & 1.77 & 1.22 \\
\hline Psych Bul & 21.5 & 41 & 0.4 & 1.6 & 1.2 & 2.0 & 6.60 & 2.60 \\
\hline Psych Med & 38.8 & 134 & 1.2 & 2.1 & 0.9 & 7.1 & 2.83 & 1.64 \\
\hline Psychia Res & 43.0 & 117 & 1.1 & 1.6 & 0.6 & 4.0 & 1.66 & 0.66 \\
\hline Psychoana Dial & 66.2 & 30 & 0.3 & 0.1 & 0.0 & 11.0 & 0.38 & 0.42 \\
\hline Psychoana $Q$ & 29.5 & 32 & 0.3 & 0.1 & 0.0 & 16.5 & 0.84 & 1.82 \\
\hline Psychotherapy & 62.1 & 68 & 0.6 & 0.6 & 0.2 & 12.5 & 0.79 & 0.49 \\
\hline Schi Bul & 46.8 & 41 & 0.4 & 1.6 & 0.5 & 5.8 & 3.97 & 2.44 \\
\hline Schi Res & 50.5 & 182 & 1.7 & 2.6 & 0.8 & 11.0 & 2.67 & 1.16 \\
\hline Science & 2.8 & 894 & 8.2 & 4.0 & 23.5 & 2.2 & 21.89 & 2.92 \\
\hline Subs Use Misu & 35.2 & 96 & 0.9 & 0.4 & 0.2 & 7.1 & 0.89 & 0.44 \\
\hline Wome Ther & 36.3 & 28 & 0.3 & 0.1 & 0.0 & 4.2 & 0.15 & 0.38 \\
\hline
\end{tabular}

Note. See Appendix D for complete journal titles. See Appendix A for an explanation of abbreviations. ${ }^{\mathrm{a}}$ Citation coverage of all 79 selected journals is $16.3 ;{ }^{\mathrm{b}} \mathrm{P}=10,866 ;{ }^{\mathrm{c}} \mathrm{C}=96,403.5 ;{ }^{\mathrm{d}} \mathrm{C}-$ all $=591,414.5$.

set of selected journals ( $\mathrm{P}$, see note b of Table 4). This indicator is based on the annual number of publications in each journal. It provides a measure of the (relative) size of the journal within the entire journal set. Taking Psychotherapy Research and Lancet as examples (see Table 4), the difference in size for both journals is evident.

The citation share indicates the contribution of each journal to the total number of citations received from and given by the selected journals (c\%) and by all ISI-covered journals (c-all\%). Total numbers are given as $\mathrm{C}$ and $\mathrm{C}$-all in notes $\mathrm{c}$ and $\mathrm{d}$ of Table 4. As compared with the citation coverage indicator, which measures the concentration of a journal on the selected set in terms of citations, the citation share indicates the role of the journal, again as measured by citations, within the selected set and 
within the entire ISI database. Table 4 demonstrates that this role is larger for Lancet than for Psychotherapy Research in the selected set (3.8 vs.0.3) and much larger, as can be expected, in the entire ISI database (9.0 vs. 0.1).

The journal self-citation percentage ( $\mathrm{JCs} \%$ ) reflects the degree of journal-tojournal self-citations in relation to the total number of citations received and issued by the selected journal. Table 4 shows very low journal self-citations for Lancet and Science.

The standard ISI IF is defined as the number of citations received in year $t$ (in this study, 2001) for publications from the years $t-1$ (2000) and $t-2$ (1999), divided by the number of publications in those 2 previous years. We recomputed the IF values, taking into account all publications assigned by ISI to one of the four main document types (i.e., articles, reviews, notes, and letters) and all citations to these publications. Note that differences may occur in comparison to IF values as published by ISI that are often based on a smaller collection of document types (citable items) and a larger volume of citations. We present this standard ISI IF because this indicator still plays an important role in journal evaluation practices.

However, as discussed, we claim that our indicator $\mathrm{JCS}_{m} / \mathrm{FCS}_{m}$ provides a more appropriate measure of journal impact, particularly when comparing journals within specific fields of science. Also, the IF is based on at most 2 citation years. This is, in our opinion, too short for the social sciences. Therefore, we include this indicator, calculated for the 5-year-period 1998 to 2001. Notice that the JCS/FCS values in Table 1 concern a longer period (1995-2002 in order to cover a reasonable number of journal volumes) and volume-years within this period, so Table 4 has a slightly different value.

\section{Construction of the Journal Landscape}

The publication and citation characteristics discussed previously concern measures of a journal such as Psychotherapy Research in relation to a group of other journals. A further step is the analysis of the citation relations between any possible pair of journals within the set of 79 journals. Thus, we created from our data system a $79 \times 79$ matrix of all possible journal-to-journal citation frequencies (data year $2001,{ }^{4}$ average of citations received and citations given, thus operating with a symmetric matrix) within this set. ${ }^{5}$ On the basis of this matrix, a two-dimensional map is constructed by applying correspondence analysis using SAS software (SAS Institute, 1996). Tijssen and Van Raan (1989), Tijssen (1992), and Noyons (1999) provide extensive discussions of the application of correspondence analysis and other multidimensional analysis techniques to bibliometric data.

Figure 2 displays a spatial configuration of the selected journals. This map represents the basic topographical structure underlying the entire citation network between the journals involved. The distance between journals is based on the strength of their mutual citation relationships. The first two dimensions cover $32.5 \%$ of the information embedded in the entire data matrix. This explained variance is considerably lower than in the case of highly interconnected journals in physics, chemistry, and medical fields (for which usually 60\% and higher is found). Indeed, our data matrix is rather sparse compared with these natural and medical science fields. Also, we average the citing and cited data; however, the citing-cited relations of most journals in our set with general high-status journals such as Lancet will be much more asymmetric than in the case of fields of basic medical fields. Nevertheless, the map presents a first insight into the

\footnotetext{
${ }^{4}$ Data derived from the CD-ROM versions of ISI Citation Indexes (in this case: SCI, SSCI).

${ }^{5}$ Data available for perusal on request.
} 


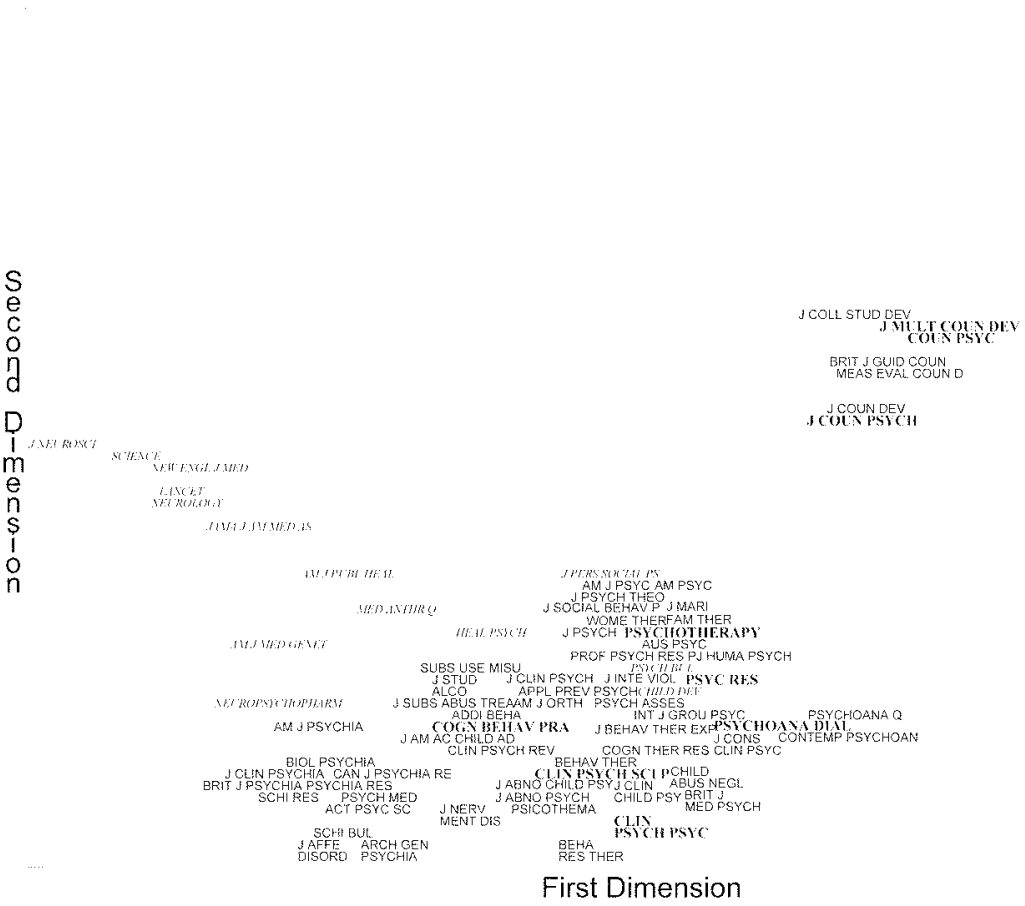

FIGURE 2. Psychotherapy research journal citation map. The journals are classified according to their citation coverage (cc; see Table 4) compared with its mean value $(M)$ and standard deviation $(S D)$ in the set of selected journals. This classification is as follows: italics label $\mathrm{cc}<M-S D$; "normal" label: $M-S D \leq \mathrm{cc} \leq M+S D$; bold label: $\mathrm{CC}>M+S D$.

landscape of journals related to Psychotherapy Research. We expect improvement in our current research by making separate maps for the citing and the cited modality for cases of less strongly and asymmetrically interconnected journals.

Citation coverage is used to enhance the map with information on the extent to which a journal concentrates its citations to the set of the 79 journals (see Figure 2). Most of the Psychotherapy Research citations (received and given) are within the set, whereas Lancet, although belonging to the set of 79 journals, has most of its citations outside the set (as already concluded).

The name of each journal is centered at its geometric position on the map. The exact location of each journal is determined by the strength of its citation relationships with each of the other journals relative to the total number of citations received and given. Interpretation of the journal configuration map should only be in terms of the (approximate) metric distance between each pair of journals. Pairs of journals with relatively strong citation ties are, on the whole, located near each other, whereas journals with a relatively weak or nonexistent citation links are distant from each other. Journals in or near the geometric center of the map have a relatively uniform distribution of citations to and from the other journals. The location of journals along the horizontal and vertical axis of the figure is, in conceptual terms, arbitrary. Conceptual meaningful axes, if any, can be obtained by rotating the entire journal configuration.

With the help of this map, editors and authors of a journal can see immediately the environment of their journal. Psychotherapy Research is positioned in about the 
middle, right-hand side of the large cluster at the lower side of Figure 2. Several other clusters and subclusters are apparent: career development (upper right side), counseling, therapy in general, psychoanalysis in particular, clinical work, psychiatry and mental disorders, addictive behavior, and a group of general multidisciplinary, medical, and health journals.

A inspection of Figure 2 suggests a first dimension, with the more practical work to the right side and the more medical/psychiatric work to the left, and perhaps a second dimension in which journals range from the hard basic science to the more soft psychoanalytical work.

Our journal-specific bibliometric analysis serves different types of users. First, an individual researcher may use the journal map to determine whether there are further journals related to the usual set of journals that might be interesting for submitting publications or reading. A librarian may use the information provided by a journal map to determine whether the institute's library has a sufficiently large set of journals given the (sub-)fields covered by the research of the institute. Publishers are interested to know the impact of journals in relation to other journals in the same (sub-)field and may use the journal map to find out whether they have "white spots" compared with other publishers in certain (sub-)fields.

Furthermore, journal citation maps can be used to study the structure of science and, particularly, development of interdisciplinary fields. Thus, they have a potential to visualize interfaces between different (sub-)fields of science and are useful for the description and delineation of interdisciplinary fields of science. See Van Raan, Visser, and Van Leeuwen (2001) for an example in medical research on environmental aspects of health.

\section{Conclusion}

Using Psychotherapy Research as an example, we discussed a set of advanced bibliometric indicators for assessment of journal performance in an international, field-specific perspective. In doing so, we introduced a novel journal impact indicator that has several important advantages compared with the classical journal IF. Another novel aspect of this study is the assessment of the impact of the citing papers. This provides valuable information on knowledge users.

Next, we discussed the positioning of Psychotherapy Research in relation to other journals. Such a landscape based on journal-to-journal citation relations reveals a multitude of interdisciplinary relations between the journal under investigation and a large number of other journals. It provides information to authors and to publishers, particularly editors, on a journal's position in relation to other journals in the same field and in related fields of research, and it shows which journals act as bridge or interface between different fields.

\section{APPENDIX A: Overview of Bibliometric Indicators}

\begin{tabular}{ll}
\hline Indicator & Description \\
\hline $\mathrm{P}$ & Number of articles (normal articles, letters, notes and reviews) of an institute \\
& $\begin{array}{l}\text { or group published in journals processed for the ISI Citation Indexes (CI). } \\
\text { Number of citations recorded in CI journals to all articles (P) of the institute } \\
\text { or group. Self-citations are not included. }\end{array}$
\end{tabular}




\section{APPENDIX A: (continued)}

\begin{tabular}{|c|c|}
\hline Indicator & Description \\
\hline СРP & $\begin{array}{l}\text { Average number of citations per publication (i.e., citation per publication } \\
\text { ratio). Self-citations are not included. }\end{array}$ \\
\hline Pnc & Percentage of articles not cited during the time period considered. \\
\hline JCS & $\begin{array}{l}\text { Average citation rate of all articles published in the journals in which } \\
\text { the institute or group has published. It is, in fact, a new journal impact } \\
\text { indicator. Self-citations are not included. In the case the "group" is a journal } \\
\text { (like in this article), than CPP =JCS. For the average citation rate of articles } \\
\text { published in a set of journals-which is mostly the case for research institutes } \\
\text { or groups- we take the mean value } \mathrm{JCS}_{m} \text { (see Appendix B for an example } \\
\text { of the calculation procedure). }\end{array}$ \\
\hline FCS & $\begin{array}{l}\text { Average citation rate of all articles in the fields in which the institute or } \\
\text { group is active (i.e., the world citation average in those fields). Fields are } \\
\text { defined by means of ISI journal categories. Self-citations are not included. } \\
\text { In a similar way as for the just-discussed JCS }{ }_{m} \text {, we take for the average } \\
\text { citation rate of articles published in more than one field, which is mostly } \\
\text { the case for research institutes or groups, the mean value } \text { FCS }_{m} \text { (again, } \\
\text { see Appendix B for an example of the calculation procedure). }\end{array}$ \\
\hline $\mathrm{CPP} / \mathrm{JCS}_{m}$ & $\begin{array}{l}\text { Impact of the articles of the institute or group compared with the average } \\
\text { citation rate of the journals. A "+" or "-" symbol behind the numerical } \\
\text { value indicates that the impact of the articles is significantly above or } \\
\text { below the average citation rate of the journals concerned. }\end{array}$ \\
\hline $\mathrm{CPP} / \mathrm{FCS}_{m}$ & $\begin{array}{l}\text { Impact of the articles of the institute or group compared with the world citation } \\
\text { average in the (sub-)fields in which the institute or group is active. A "+" or } \\
\text { "-" symbol behind the numerical value indicates that the impact of the } \\
\text { articles is significantly above or below world average of the fields concerned. }\end{array}$ \\
\hline $\mathrm{JCS}_{m} / \mathrm{FCS}_{m}$ & $\begin{array}{l}\text { Impact of the journal in which the institute or group has published } \\
\text { compared with the world citation average based on all journals in the } \\
\text { fields concerned. This indicator is the new journal impact indicator } \mathrm{JCS}_{m} \\
\text { normalized to the average citation rate of the field } \mathrm{FCS}_{m} \text {. }\end{array}$ \\
\hline Scit & $\begin{array}{l}\text { Percentage of self-citations. A self-citation is defined as a citation in which } \\
\text { the citing and the cited paper have at least one author in common (first } \\
\text { author or coauthor). }\end{array}$ \\
\hline
\end{tabular}

\section{APPENDIX B: Calculation of $\mathrm{JCS}_{m}$ and $\mathrm{FCS}_{m}$}

We take, as an example, an "oeuvre" of a research group consisting of four publications (I, II, III, IV) of different article types in the given journals belonging to specific fields. In the right-hand part of the table, the indicator CPP is for each publication separately $(\mathrm{P}=1$; thus, it is in this case simply the number of citations up to 1999). JCS and FCS are the indicators for the given individual journals and fields, respectively, with numerical values for the indicated period (in case of publication I, it is 1996-1999; for publication II,1997-1999; and for publications III and IV, 1999).

\begin{tabular}{llcllcrr}
\hline & & Publication & & \multicolumn{3}{c}{ Citations up to } \\
& Article type & year & Journal & Field & 1999=CPP & JCS & FCS \\
\hline I & Review & 1996 & Cancer Res & Oncology & 17 & 16.9 & 23.7 \\
II & Note & 1997 & J Clin End & Endocrinology & 4 & 3.1 & 3.0 \\
\hline
\end{tabular}




\begin{tabular}{llcllcrr}
\hline & & Publication & & & Citations up to \\
& Article type & year & Journal & Field & 1999=CPP & JCS & FCS \\
\hline III & Article & 1999 & J Clin End & Endocrinology & 6 & 4.8 & 4.1 \\
IV & Article & 1999 & J Clin End & Endocrinology & 8 & 4.8 & 4.1 \\
\hline
\end{tabular}

Note. See Appendix D for complete journal titles. See Appendix A for an explanation of abbreviations.

We now calculate the bibliometric indicators CPP, JCS ${ }_{m}$, and $\mathrm{FCS}_{m}$ for the entire "oeuvre" of four publications: $\mathrm{CPP}=(17+4+6+8) /(1+1+1+1)=8.75 ; \quad \mathrm{JCS}_{m}=$ $\{(1 \times 16.9)+(1 \times 3.1)+(2 \times 4.8)\} /(1+1+2)=7.40 ; \mathrm{FCS}_{m}=\{(1 \times 23.7)+(1 \times 3.0)+(2 \times 4.1)\} /$ $(1+1+2)=8.72$; Hence, $\mathrm{CPP} / \mathrm{JCS}_{m}=8.750 / 7.40=1.18$, and $\mathrm{CPP} / \mathrm{FCS}_{m}=8.75 / 8.72=1.003$.

\section{APPENDIX C: Profile of the Citing Papers of Psychotberapy Research (Knowledge Users; First 15 Fields)}

\begin{tabular}{|c|c|c|c|c|c|c|c|c|c|c|}
\hline Field & $\mathrm{P}$ & $\%$ & $\mathrm{C}$ & $\mathrm{C}+\mathrm{sc}$ & СРP & Pnc & $\begin{array}{l}\mathrm{CPP} / \\
\mathrm{JCS}_{\mathrm{m}}\end{array}$ & $\begin{array}{l}\mathrm{CPP} / \\
\mathrm{FCS}_{\mathrm{m}}\end{array}$ & $\begin{array}{l}\mathrm{JCS}_{\mathrm{m}} \\
\mathrm{FCS}_{\mathrm{m}}\end{array}$ & Scit \\
\hline Psychology, $\mathrm{CL}^{\mathrm{a}, \mathrm{b}}$ & 310.5 & $54 \%$ & 972.5 & $1,280.7$ & 3.13 & $44 \%$ & 1.05 & 1.17 & 1.11 & $24 \%$ \\
\hline Psychiatry $^{\mathrm{a}}$ & 47.2 & $8 \%$ & 129.3 & 168.3 & 2.74 & $46 \%$ & 0.84 & 0.77 & 0.91 & $23 \%$ \\
\hline Psychology, $\mathrm{MU}^{\mathrm{a}, \mathrm{c}}$ & 33.4 & $6 \%$ & 208.1 & 254.5 & 6.22 & $33 \%$ & 1.92 & $3.30+$ & 1.72 & $18 \%$ \\
\hline Psychology, $\mathrm{AP}^{\mathrm{a}, \mathrm{d}}$ & 29.3 & $5 \%$ & 90.0 & 110.5 & 3.07 & $39 \%$ & 1.04 & 1.33 & 1.27 & $19 \%$ \\
\hline Psychiatry ${ }^{\mathrm{e}}$ & 28.1 & $5 \%$ & 81.8 & 109.1 & 2.91 & $39 \%$ & 0.68 & 0.76 & 1.12 & $25 \%$ \\
\hline Psychology, PS ${ }^{\mathrm{a}, \mathrm{f}}$ & 21.3 & $4 \%$ & 37.5 & 46.2 & 1.76 & $31 \%$ & 1.46 & $1.95+$ & 1.33 & $19 \%$ \\
\hline Psychology, SO $\mathrm{SO}^{\mathrm{a}, \mathrm{g}}$ & 17.0 & $3 \%$ & 21.5 & 36.0 & 1.26 & $50 \%$ & 1.25 & 0.77 & 0.61 & $40 \%$ \\
\hline Psychology, ED ${ }^{\mathrm{a}, \mathrm{h}}$ & 14.8 & $3 \%$ & 52.3 & 81.8 & 3.53 & $30 \%$ & 0.94 & 1.64 & 1.75 & $36 \%$ \\
\hline Psychology, DE ${ }^{\mathrm{a}, \mathrm{i}}$ & 10.3 & $2 \%$ & 16.5 & 19.8 & 1.61 & $49 \%$ & 0.73 & 0.62 & 0.85 & $16 \%$ \\
\hline Psychology & 8.8 & $2 \%$ & 76.5 & 86.0 & 8.66 & $25 \%$ & 1.22 & 2.08 & 1.71 & $11 \%$ \\
\hline Clinical neurology & 5.8 & $1 \%$ & 14.3 & 20.3 & 2.46 & $57 \%$ & 1.00 & 0.70 & 0.69 & $30 \%$ \\
\hline Substance abuse $\mathrm{e}^{\mathrm{e}}$ & 5.7 & $1 \%$ & 11.4 & 20.9 & 2.01 & $35 \%$ & 0.72 & 0.78 & 1.09 & $45 \%$ \\
\hline Substance abuse $\mathrm{a}^{\mathrm{a}}$ & 5.7 & $1 \%$ & 7.4 & 9.4 & 1.31 & $62 \%$ & 2.22 & 2.63 & 1.19 & $21 \%$ \\
\hline Family studies ${ }^{\mathrm{a}}$ & 4.0 & $1 \%$ & 4.5 & 5.5 & 1.13 & $50 \%$ & 0.83 & 0.69 & 0.83 & $18 \%$ \\
\hline 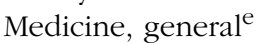 & 4.0 & $1 \%$ & 13.0 & 17.0 & 3.25 & $50 \%$ & 0.35 & 0.55 & 1.56 & $24 \%$ \\
\hline
\end{tabular}

Note. $\mathrm{CPP} / \mathrm{FCS}_{m}$ values are in boldface type because this is our "crown indicator." See Appendix A for an explanation of abbreviations.

${ }^{\mathrm{a}}$ Journal categories covered by the SSCI; ${ }^{\mathrm{b}}$ Psychology, $\mathrm{CL}=$ clinical psychology; ${ }^{\mathrm{c}}$ Psychology, $\mathrm{MU}=$ multidisciplinary (i.e., general) psychology; ${ }^{\mathrm{d}}$ Psychology, AP = applied psychology; ${ }^{\mathrm{e}} \mathrm{Journal}$ cate-

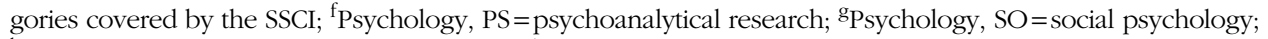
${ }^{\mathrm{h}}$ Psychology, ED = educational psychology; ${ }^{\mathrm{i}}$ Psychology, DE = developmental psychology.

\section{Appendix D: Abbreviation and Full Name of Journal Titles}

\begin{tabular}{ll}
\hline Abbreviation & Full name \\
\hline Act Psyc Sc & Acta Psychiatrica Scandinavica \\
Addi Beha & Addictive Behaviors \\
Am J Med Genet & American Journal of Medical Genetics \\
Am J Orth & American Journal of Orthopsychiatry \\
Am J Psyc & American Journal of Psychotherapy \\
Am J Psychia & American Journal of Psychiatry \\
Am J Publ Heal & American Journal of Public Health \\
Am Psyc & American Psychologist \\
Appl Prev Psych & Applied E Preventive Psychology
\end{tabular}


APPENDIX D: (continued)

\begin{tabular}{|c|c|}
\hline Abbreviation & Full name \\
\hline Arch Gen Psychia & Archives of General Psychiatry \\
\hline Aus Psyc & Australian Psychologist \\
\hline Beha Res Ther & Behaviour Research and Therapy \\
\hline Behav Ther & Behavior Therapy \\
\hline Biol Psychia & Biological Psychiatry \\
\hline Brit J Guid & British Journal of Guidance $\varepsilon$ Counselling \\
\hline Brit J Med Psych & British Journal of Medical Psychology \\
\hline Brit J Psychia & British Journal of Psychiatry \\
\hline Can J Psychia Revu C & Canadian Journal of Psychiatry-Revue Canadienne de Psychiatrie \\
\hline Cancer Res & Cancer Research \\
\hline Care Dev Q & Career Development Quarterly \\
\hline Child Abus Negl & Child Abuse \& Neglect \\
\hline Child Dev & Child Development \\
\hline Clin Psych Psyc & Clinical Psychology \& Psychotherapy \\
\hline Clin Psych Rev & Clinical Psychology Review \\
\hline Clin Psych Sci Pra & Clinical Psychology: Science and Practice \\
\hline Cogn Behav Pra & Cognitive and Behavioral Practice \\
\hline Cogn Ther Res & Cognitive Therapy and Research \\
\hline Contemp Psychoana & Contemporary Psychoanalysis \\
\hline Coun Psyc & Counseling Psychologist \\
\hline Heal Psych & Health Psychology \\
\hline Int J Grou Psyc & International Journal of Journal Psychotherapy \\
\hline J Abno Child Psych & Journal of Abnormal Child Psychology \\
\hline J Abno Psych & Journal of Abnormal Psychology \\
\hline J Affe Disord & Journal of Affective Disorders \\
\hline J Am Ac Child Adol P & Journal of the American Academy of Child and Adolescent Psychiatry \\
\hline J Behav Ther Exp Psy & Journal of Behavior Therapy and Experimental Psychiatry \\
\hline J Care Asses & Journal of Career Assessment \\
\hline J Care Dev & Journal of Career Development \\
\hline J Clin Child Psych & Journal of Clinical Child Psychology \\
\hline J Clin End & Journal of Clinical Endocrinology and Metabolism \\
\hline J Clin Psych & Journal of Clinical Psychology \\
\hline J Clin Psychia & Journal of Clinical Psychiatry \\
\hline J Coll Stud Dev & Journal of College Student Development \\
\hline J Cons Clin Psych & Journal of Consulting and Clinical Psychology \\
\hline$J$ Coun Dev & Journal of Counseling and Development \\
\hline J Coun Psych & Journal of Counseling Psychology \\
\hline J Huma Psych & Journal of Humanistic Psychology \\
\hline J Inte Viol & Journal of Interpersonal Violence \\
\hline J Mari Fam Ther & Journal of Marital and Family Therapy \\
\hline J Mult Coun Dev & Journal of Multicultural Counseling and Development \\
\hline J Nerv Ment Dis & Journal of Nervous and Mental Disease \\
\hline J Neurosci & Journal Of Neuroscience \\
\hline J Pers Social Psych & Journal of Personality and Social Psychology \\
\hline JPsych & Journal of Psychology \\
\hline JPsych Theo & Journal of Psychology and Theology \\
\hline J Social Behav Pers & Journal of Social Behavior and Personality \\
\hline J Stud Alco & Journal of Studies on Alcohol \\
\hline J Subs Abus Trea & Journal of Substance Abuse Treatment \\
\hline
\end{tabular}


APPENDIX D: (continued)

\begin{tabular}{ll}
\hline Abbreviation & Full name \\
\hline J Voca Behav & Journal of Vocational Behavior \\
JAMA & Journal of the American Medical Association \\
Lancet & Lancet \\
Meas Eval Coun Dev & Measurement and Evaluation in Counseling and Development \\
Med Anthr Q & Medical Anthropology Quarterly \\
Neurology & Neurology \\
Neuropsychopharmacol & Neuropsychopharmacology \\
New EnglJMed & New England Journal of Medicine \\
Prof Psych Res Prap & Professional Psychology: Research and Practice \\
Psicothema & Psicothema \\
Psyc Res & Psychotherapy Research \\
Psych Asses & Psychological Assessment \\
Psych Bul & Psychological Bulletin \\
Psych Med & Psychological Medicine \\
Psychia Res & Psychiatry Research \\
Psychoana Dial & Psychoanalytic Dialogues \\
Psychoana Q & Psychoanalytic Quarterly \\
Psychotherapy & Psychotherapy \\
Schi Bul & Schizophrenia Bulletin \\
Schi Res & Schizophrenia Research \\
Science & Science \\
Subs Use Misu & Substance Use E Misuse \\
Wome Ther & Women \& Therapy \\
\hline
\end{tabular}

\section{References}

Glänzel, W. (1992). Publication dynamics and citation impact: A multi-dimensional approach to scientometric research evaluation. In $\mathrm{P}$. Weingart, R. Sehringer, \& M. Winterhager (Eds.), Representations of science and technology (pp. 209-224). Leiden, the Netherlands: DSWO Press.

Horrobin, D. F. (1990). The philosophical basis of peer review and the suppression of innovation. Journal of the American Medical Association, 263, 1438-1441.

Meertens, R. W., Nederhof, A. J., \& Wilke, H. A. M. (1992). Social psychological research in The Netherlands, 1980-1988. European Journal of Social Psychology, 22, 93-100.

Moed, H. F., De Bruin, R. E., \& Van Leeuwen, T. N. (1995). New bibliometric tools for the assessment of national research performance: Database description, overview of indicators and first applications. Scientometrics, 33, 381-422.

Moed, H. F., \& Van Leeuwen, T. N. (1995). Improving the accuracy of the Institute for Scientific Information's journal impact factors. Journal of the American Society for Information Science, 46, 461-467.
Moed, H. F., \& Van Leeuwen, T. N. (1996). Impact factors can mislead. Nature, 381, 186.

Moxham, H., \& Anderson, J. (1992). Peer review. A view from the inside. Science and Technology Policy, 5, 7-15.

Nederhof, A. J., Van Leeuwen, T. N., \& Visser, M. S. (1997). A comparative bibliometric study of the Kurt Lewin Institute (CWTS-report 199710). Leiden, the Netherlands: CWTS.

Nederhof, A. J., Van Leeuwe, T. N., \& Visser, M. S. (2000). Bibliometric profiles of academic psychology in The Netherlands (CWTS-report 2000-05). Leiden, the Netherlands: CWTS.

Noyons, E. C. M. (1999). Bibliometric mapping as a science policy and research management tool. Leiden, the Netherlands: DSWO Press.

Rinia, E. J., Van Leeuwen, T. N., Van Vuren, H. G., \& Van Raan, A. F. J. (1998). Comparative analysis of a set of bibliometric indicators and central peer review criteria. Evaluation of condensed matter physics in the Netherlands. Research Policy, 27, 95-107.

SAS Institute. (1996). SAS//STAT software: Changes and enhancements through release 6.11. Cary, NC: Author. 
Schubert, A., \& Glänzel, W. (1983). Statistical reliability of comparisons based on the citation impact of scientific publications. Scientometrics, 5, 59-74.

Tijssen, R. J. W. (1992). Cartography of science: Scientometric mapping with multidimensional scaling methods. Leiden, the Netherlands: DSWO Press.

Tijssen, R. J. W., \& Van Raan, A. F. J. (1989). Mapping co-word structures: A comparison of multidimensional scaling and Leximappe. Scientometrics, 15, 283-295.

Van Raan, A. F. J. (1996). Advanced bibliometric methods as quantitative core of peer review based evaluation and foresight exercises. Scientometrics, 36, 397-420.
Van Raan, A. F. J. (1998). Assessing the social sciences: The use of advanced bibliometric methods as a necessary complement of peer review. Research Evaluation, 7, 2-6.

Van Raan, A. F. J., Visser, M., \& Van Leeuwen, T. N. (2001). A bibliometric methodology for exploring interdisciplinary, "unorthodox" fields of science. A case study of environmental medicine. In S. Maasen \& M. Wintherhager (Eds.), Science studies. Probing the dynamics of scientific knowledge (pp. 87-122). Bielefeld: Transcript Verlag.

VSNU. (1999). Assessment of research quality: Psychology. Utrecht, The Netherlands: VSNU.

\section{Zusammenfassung}

Die Autoren geben einen Überblick über weiterentwickelte bibliographische Methoden (a) zur objektiven und transparenten Beurteilung der Leistung einer Zeitschrift und (b) der Positionierung einer Zeitschrift im Vergleich zu anderen Zeitschriften. Diese Methoden werden auf eine internationale Zeitschrift im Bereich der Klinischen Psychologie, nämlich Psychotherapy Research, angewandt. In der ersten Analyse wird die Leistung der Zeitschrift in einer international vergleichenden Perspektive untersucht (das heißt, die Leistung der Zeitschrift wird in Beziehung zu allen anderen Zeitschriften im selben Wissenschaftsbereich betrachtet) und es wird ein neuer Typ eines Zeitschriften-Impact-Faktor eingeführt. In der zweiten Analyse wird die Zeitschrift auf der Basis aller Zitierungsbeziehungen zwischen allen relevanten Zeitschriften, inklusive der Zeitschriften außerhalb des spezifischen Wissenschaftsbereichs, zu dem die Zeitschrift gehört, positioniert. Eine Vielfalt interdisziplinärer Beziehungen zwischen der untersuchten Zeitschrift und vielen anderen Zeitschriften wird aufgezeigt. In der Diskussion gegen die Autoren kurz auf das Potential einer solchen "ZeitschriftenZitierungsabbildung" für das Verständnis interdisziplinärer Entwicklungen und der Beziehungsmatrix zwischen verschiedenen Wissenschaftsbereichen ein.

\section{Résumé}

Les auteurs offrent un résumé des méthodes bibliométriques avancées pour (a) une évaluation objective et transparente de la performance d'un journal et (b) le positionnement d'un journal en relation avec d'autres journaux. Ces méthodes sont appliquées à Psychotherapy Research, une revue internationale dans le champ de la psychologie clinique. Dans la première analyse, les auteurs mettent le focus sur la performance de la revue dans une perspective comparative internationale (la performance de la revue en relation avec toutes les autres revues dans le même champ scientifique), et ils introduisent un nouveau type de facteur d'impact d'une revue. Dans la seconde analyse, les auteurs positionnent le journal sur la base des relations de citations totales parmi toutes les revues d'importance y comprises celles en dehors du champ scientifique spécifique auquel appartient la revue. Une multitude de relations interdisciplinaires entre la revue examinée et de nombreuses autres revues sont révélées. Les investigateurs discutent brièvement le potentiel d'une telle "cartographie des citations de publications" pour démêler des développements interdisciplinaires et des "interfaces" entre différents champs de science.

\section{Resumen}

Los autores presentan una visión general de métodos bibliométricos avanzados para (a) una evaluación objetiva y transparente del desempeño de las revistas (journal performance) y (b) el posicionamiento de una revista en relación con otras. Estos métodos se aplican a Psychotherapy Research, una revista internacional dentro del campo de la psicología clínica. En el primer análisis, los autores focalizan el desempeño de la revista dentro de una perspectiva comparativa internacional (esto es, el desempeño de la revista en relación con todas las otras revistas del mismo campo de la ciencia) e introducen un tipo nuevo de factor de impacto de una revista. En el segundo análisis, los autores posicionan la revista sobre la base del total de citas de todas las revistas pertinentes, incluidas las de fuera del campo específico de la ciencia a la cual pertenece la revista. Se descubre una multitud de relaciones interdisciplinarias entre 
la revista bajo investigación y muchas otras revistas. Los investigadores discuten brevemente el potencial de tal "mapeo de citas de la revista" para descubrir desarrollos interdisciplinarios e "interfaces" entre diferentes campos de la ciencia.

\section{Resumo}

Os autores providenciam uma visão geral de métodos bibliométricos avançados para (a) uma avaliação objectiva e transparente do desempenho das revistas e (b) para o posicionamento duma revista em relação a outras revistas. Estes métodos são aplicados à Psychotherapy Research, uma revista internacional no âmbito da psicologia clínica. Na primeira análise, os autores focam-se no desempenho da revista numa perspectiva de comparação internacional (i.e., o desempenho da revista em relação a todas as outras revistas do mesmo campo da ciência) e introduzem um tipo inovador de factor de impacto da revista. Na segunda análise, os autores posicionam a revista com base na relação do total de citações em todas as revistas relevantes, incluindo aquelas fora do campo científico específico ao qual a revista pertence. É revelada uma multiplicidade de relações interdisciplinares entre a revista em estudo e muitas outras revistas. Os investigadores tecem uma breve discussão sobre o potencial de tal "mapa de citações em revistas" para desvendar os desenvolvimentos interdisciplinares e para criar interfaces entre os diferentes campos da ciência.

\section{Sommario}

Gli autori forniscono una visione d'insieme dei più avanzati metodi bibliometrici per (a) una valutazione oggettiva e transparente del rendimento di una rivista e (b) per posizionare, confrontare una rivista rispetto ad altre. Questi metodi sono stati applicati a Psychotherapy Research, una rivista internazionale appartenente all'area della psicologia clinica. Per prima cosa, gli autori hanno valutato il rendimento della rivista a livello internazionale confrontandola cioè con le riviste internazionali appartenenti alla medesima area tematica, introducendo inoltre un nuovo tipo di fattore nella valutazione del peso della rivista. In seconda analisi, gli autori hanno valutato la posizione della rivista rispetto ad altre utilizzando come metro di misura il numero di citazioni in altre riveste, anche non appartenenti alla stessa area scientifica. Sono state rilevate un notevole numero di relazioni interdisciplinari tra la rivista oggetto di studio ed altre pubblicazioni. Infine gli autori discutono brevemente le potenzialità di "una mappa delle citazioni di una rivista" per scoprire ed evidenziare I collegamenti interdisciplinari tra differenti campi della scienza.

\section{摔要}

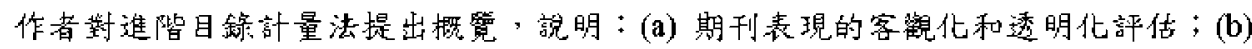

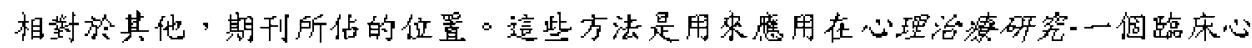

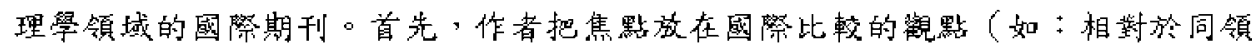
域中的其他期刊, 期刊的表现如何) 束看期刊的表現, 由此引出一個新預的期刊

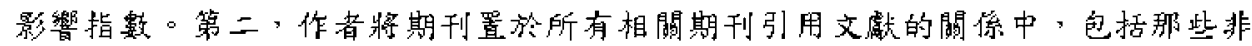
期刊所显的特殊科學領域。结果發现本研究所探討的期刊和許多其他期刊之間,

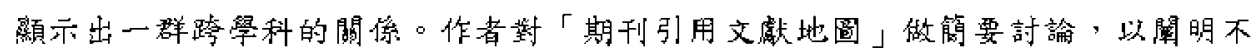
同學科間的發展以及不同科學領域的界面之可能性。

Received April 23, 2003

Revision received July 2, 2003

Accepted July 10, 2003 